\title{
SARS-CoV-2 vaccine research and immunization strategies for improved control of the COVID-19 pandemic
}

\author{
Yiming Shao $(\varangle)^{1,2}$, Yingqi Wu ${ }^{1}$, Yi Feng ${ }^{1}$, Wenxin $\mathrm{Xu}^{3}$, Feng Xiong $(\varangle)^{4}$, Xinxin Zhang $(\varangle)^{3}$ \\ ${ }^{1}$ Chinese Center for Disease Control and Prevention, Beijing 102206, China; ${ }^{2}$ Changping Laboratory, Beijing 102206, China ; ${ }^{3}$ Department \\ of Infectious Diseases, Research Laboratory of Clinical Virology, National Research Center for Translational Medicine at Shanghai, Ruijin \\ Hospital Affiliated to Shanghai Jiao Tong University School of Medicine, Shanghai 200025, China ; ${ }^{4}$ Department of Policy Science, Central \\ Committee of the Chinese Peasants and Workers Democratic Party, Beijing 100011, China \\ (C) Higher Education Press 2022
}

\begin{abstract}
The record speed at which Chinese scientists identified severe acute respiratory syndrome coronavirus 2 (SARS-CoV-2) and shared its genomic sequence with the world, has greatly facilitated the development of coronavirus disease (COVID-19) diagnostics, drugs, and vaccines. It is unprecedented in pandemic control history to develop a dozen successful vaccines in the first year and to immunize over half of the global population in the second year, due to the efforts of the scientific community, biopharmaceutical industry, and regulatory agencies worldwide. The challenges are both great and multidimensional due to the rapid emergence of virus variants and waning of vaccine immunity. Vaccination strategies need to adapt to these challenges to keep population immunity above the herd immunity threshold, by increasing vaccine coverage, especially for older adults and young people, and providing timely booster doses with homologous or heterologous vaccine boosts. Further research should be undertaken to develop more effective vaccines against SARS-CoV-2 variants and to understand the best primeboost vaccine combinations and immunization strategies to provide sufficient and sustainable immune protection against COVID-19.
\end{abstract}

Keywords COVID-19; pandemics; SARS-CoV-2; vaccination

\section{Rapid development of SARS-CoV-2 vaccines}

In less than two years, coronavirus disease (COVID-19) has significantly changed the world, with over 255 million people infected by severe acute respiratory syndrome coronavirus 2 (SARS-CoV-2) and the heavy loss of over 5 million lives [1]. Chinese scientists identified and isolated SARS-CoV-2 within two weeks of the first reported cases of COVID-19, in late December 2019 [2,3]. In the first year of the COVID-19 pandemic, the whole world had to rely on non-pharmaceutical interventions (NPI), i.e., public health strategies to control the spread of SARS-CoV-2 within and beyond the country's borders and to simulta-

Received November 25, 2021; accepted December 13, 2021

Correspondence: Yiming Shao, yshao@chinaaids.cn;

Xinxin Zhang, zhangx@shsmu.edu.cn;

Feng Xiong, xiongfeng@ngd.org.cn neously treat the patients to save lives. Within hours of Chinese scientists sharing the SARS-CoV-2 full genomic sequence on an international public database (GISAID) in early January 2020 [4-6], scientists from public and private research institutes and pharmaceutical companies worldwide started to develop SARS-CoV-2 vaccines. In record time, several different types of vaccine were produced in both developed and developing countries.

Regulatory agencies in these countries accelerated their review and approval processes to meet the urgent needs of COVID-19 pandemic control. The inactivated vaccines of Sinopharm and Sinovac were approved for emergency use in July 2020, in China. Initially, they were used for vaccinating key figures in pandemic control, including frontline doctors, nurses, public health professionals, and public servants, especially those at the community level, as well as workers on the land borders, airports, and seaports. The adenoviral vector (Ad26/Ad5) vaccines of Gamaleya's Sputnik V (Gam-COVID-Vac) were approved in August 2020, for emergency use in Russia. The Pfizer-BioNTech and Moderna COVID-19 mRNA vaccines, were approved 
for emergency use in the US in December 2020 and in the EU in December 2020 and January 2021, respectively. The Champ adenoviral vector vaccine of AstraZeneca (AZ) COVID-19 vaccine was approved for emergency use in the UK in December 2020 and in the EU in January 2021. The inactivated Bharat Biotech BBV152 COVAXIN vaccine was approved for emergency use in India in January 2021. The Johnson and Johnson (J\&J)/Janssen adenoviral 26 vector COVID-19 vaccine was approved for emergency use in the US in February 2021 and in the EU in March 2021. The Anhui-Zhifei recombinant protein vaccine was approved for emergency use in China in March 2021. The Chinese Sinopharm, Sinovac and CanSino (adenovirus 5 vector) vaccines also obtained conditional marketing authorization in China in late 2020 and early 2021, respectively (Fig. 1A).

These COVID-19 vaccines were the most widely administered worldwide by the end of October 2021. The contribution from each vaccine type was: Sinovac and AZ both over 2 billion doses, Sinopharm and PfizerBioNTech each close to 2 billion doses, Moderna, Sputnik $\mathrm{V}$, and $\mathrm{J} \& \mathrm{~J}$ each over 100 million doses, and Bharat and Anhui-Zhifei each in the tens of million doses (Fig. 1B) [7]. The WHO has approved seven of these ten vaccines, excluding the Gamaleya, CanSino, and Anhui-Zhifei vaccines, for emergency use.

\section{The importance of maintaining high vaccination coverage}

In the second year of pandemic control, countries employed both vaccines and NPI public health measures. International standards set the SARS-CoV-2 vaccine clinical trial end point as the prevention of COVID-19 symptoms, with the aim of secondary prevention. All

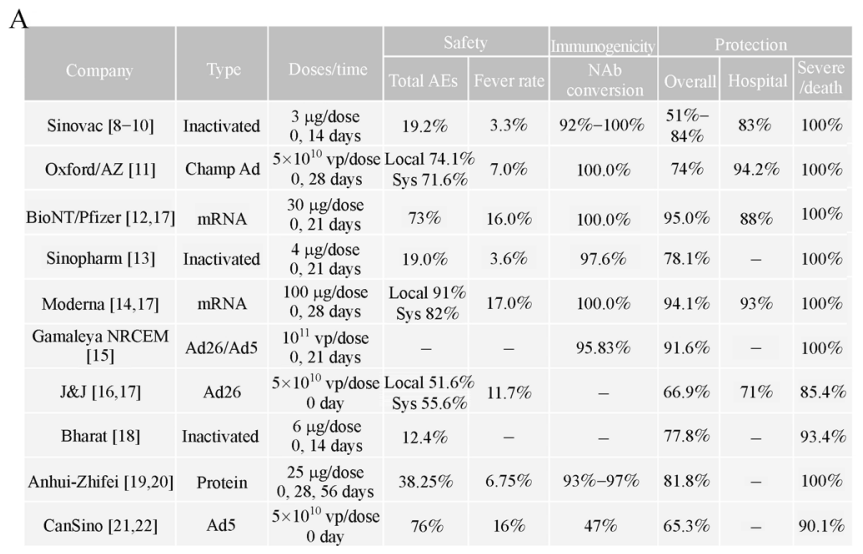

approved SARS-CoV-2 vaccines achieved the goal of preventing over $80 \%-90 \%$ of COVID-19 hospitalizations, severe disease, and death, despite having wider disparities of $50 \%-90 \%$ in the prevention of mild symptoms (Fig. 1A [8-22]). Therefore, all current vaccines have strong efficacy in the reduction of COVID-19 severe cases and mortality and have less effects on the control of viral infection and mild symptoms. Therefore, a clear reverse correlation is found between SARS-CoV-2 vaccine coverage and COVID-19 mortality in many countries (Fig. 2 $[23,24])$. To better control the COVID-19 morbidity and mortality in the world, efforts are needed to rapidly increase the vaccine coverage in all countries, while continuing and further optimizing NPI public health control measures.

Similar scenarios can be observed in many countries, as shown in Fig. 3. In early 2021, the SARS-CoV-2 infection and mortality waves that occurred across continents were controlled initially by increased vaccine coverage in these countries. With the appearance of the Delta variant and waning vaccine immunity, SARS-CoV-2 infections rebounded rapidly again, without significantly increased severity and mortality, in countries with higher vaccine coverage (UK, Germany, France, Japan, Chile, and Australia), in contrast to the increased severity and mortality of cases in countries with low or insufficient vaccine coverage (Hungary, Croatia, Romania, Russian, and the Philippines) (Fig. $3[23,24]$ ). Lessons should be taken from countries with insufficient vaccine coverage in the older-adult population, such as the 80 years older age groups in Hungary and Croatia, which compromises effective control of COVID-19 mortality (Fig. 4 [2325]). Since older adults have the highest COVID-19 mortality, countries should invest more resources and find better strategies to achieve and sustain higher vaccine coverage for senior citizens.

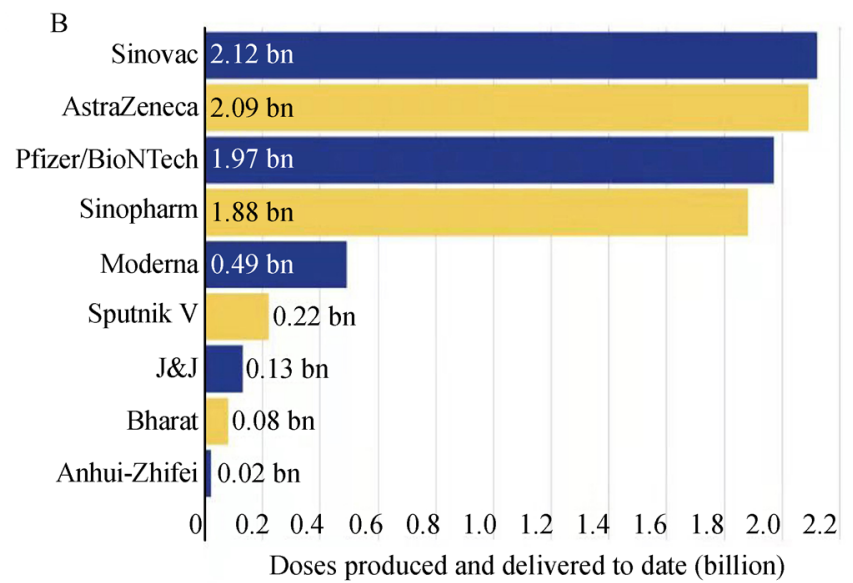

Fig. 1 The key features and delivery of COVID-19 vaccines. (A) Key features of COVID-19 vaccines. (B) Delivery amounts. bn, billion. (Reused from CGTN Europe [7] with permission.) 
COVID-19 vaccination rate $\quad$ Mortality per million population (2021.1.1-2021.11.16)

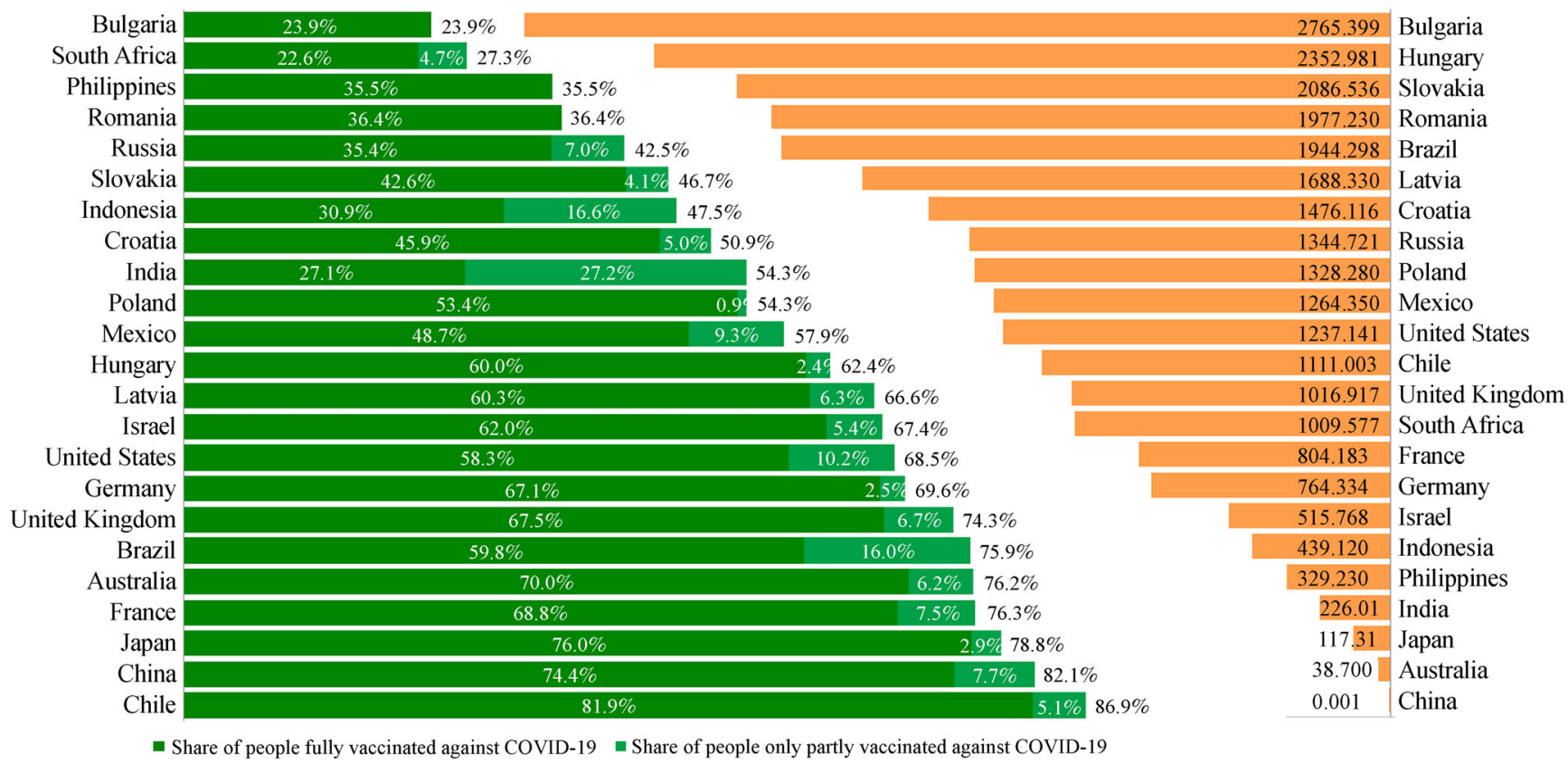

Fig. 2 COVID-19 vaccination and case mortality rates in selected countries. (Reused from https://ourworldindata.org/covidvaccinations [23] and https://ourworldindata.org/covid-cases [24] with permission.)

A
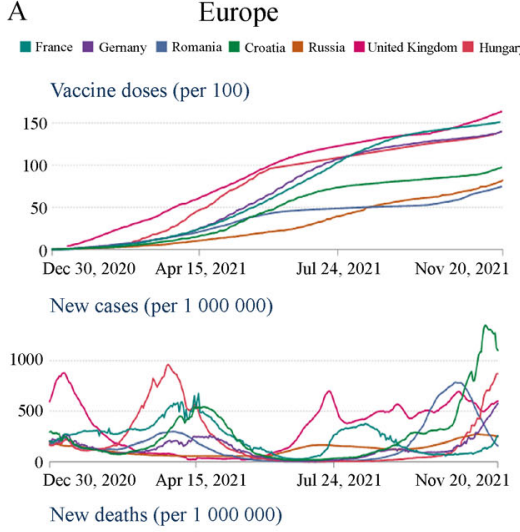

New deaths (per 1000000$)$

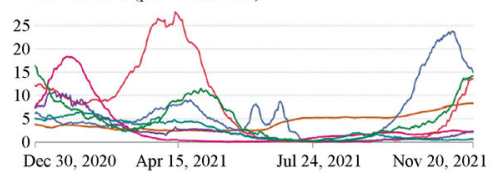

B

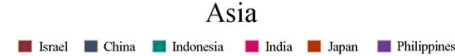

Vaccine doses (per 100)

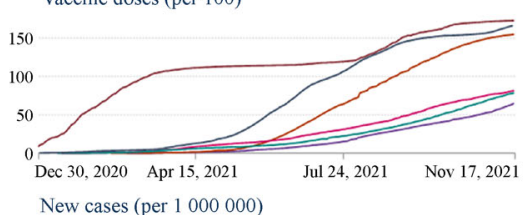

New cases (per 1000000 )

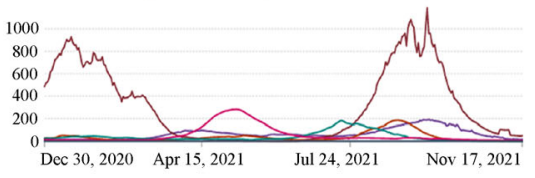

New deaths (per 1000 000)

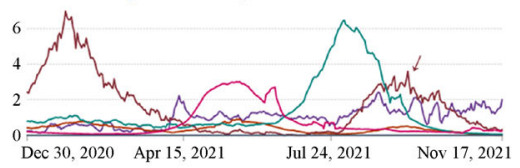

C America

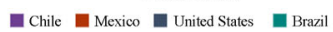

Vaccine doses (per 100)
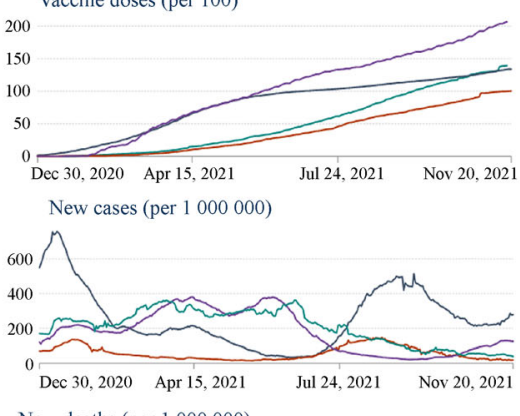

New deaths (per 1000000 )

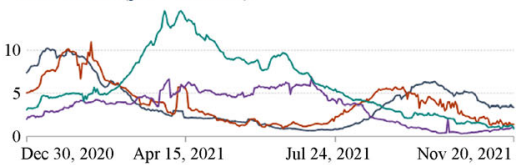

Fig. 3 Relationship between vaccination rates and incidence and mortality rates of COVID-19. (Reused from https://ourworldindata. org/covid-vaccinations [23] and https://ourworldindata.org/covid-cases [24] with permission.)

\section{The waning of vaccine immunity and emergence of viral variants}

Scientists typically look at antibody levels, or titers, as an important indicator of vaccine effectiveness. However, early indications suggest that antibody levels induced by most COVID-19 vaccines are falling with time after vaccination. On October 4, 2021, American scholars published research on more than 3.4 million people in The Lancet regarding the effectiveness of the Pfizer- 

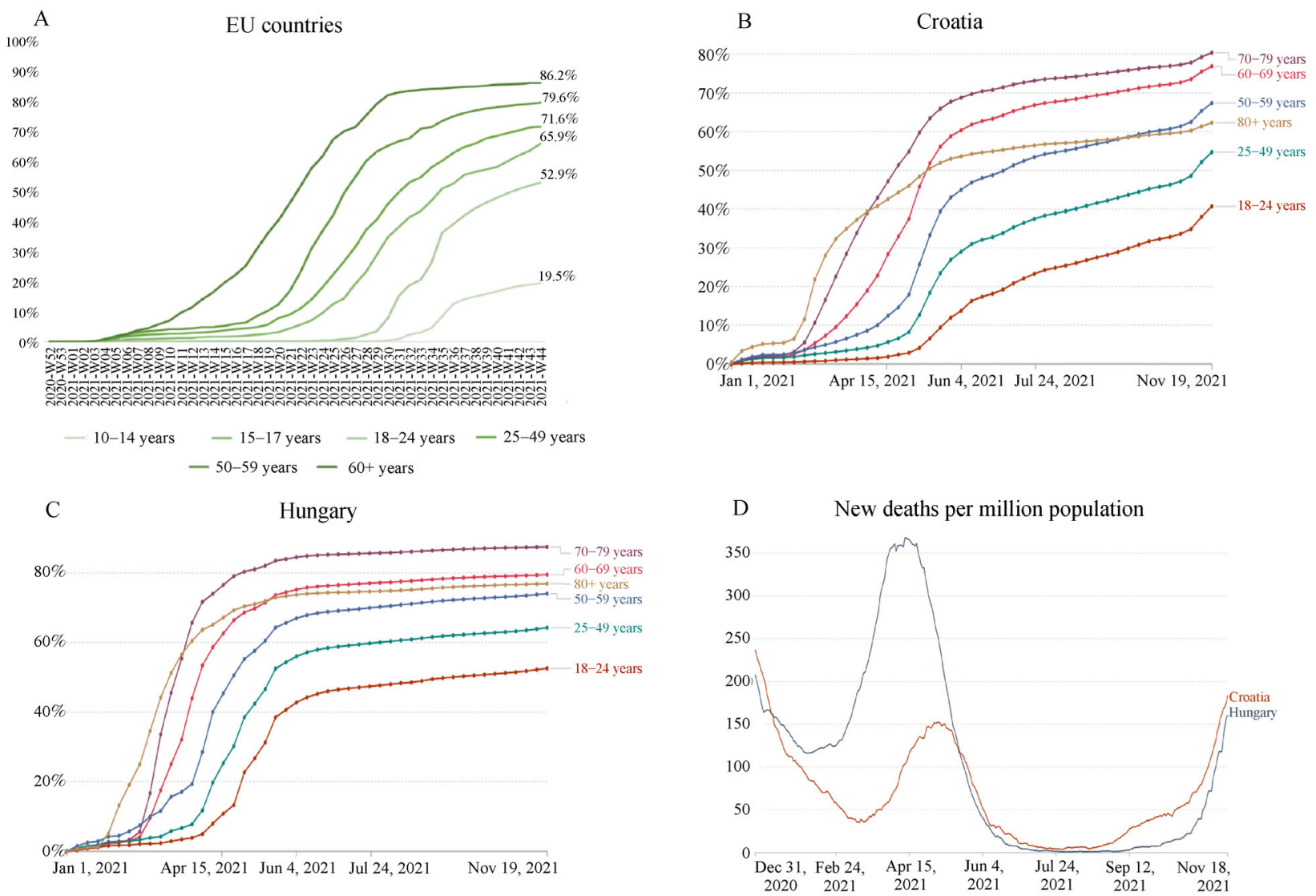

Fig. 4 COVID-19 vaccination rate by age group in the EU. (Reused from https://www.ecdc.europa.eu/en/publications-data/overviewimplementation-covid-19-vaccination-strategies-and-deployment-plans [25], https://ourworldindata.org/covid-vaccinations [23], and https://ourworldindata.org/covid-cases [24] with permission.)

BioNTech (BNT162b2) vaccine [26]. The results show that protection against infection declined from $88 \%$, during the first month after full vaccination, to $47 \%$ after 5 months. This reduction in vaccine effectiveness over time is primarily due to waning immunity, although the Delta variant evading full vaccine protection effects could also play a role. A large, long-term follow-up of vaccine trials from several countries, released in September 2021, reveals a similar story; the efficacy of the BNT162b2 mRNA vaccine against SARS-CoV-2 dropped from $96.2 \%$ at its peak after the second dose to $83.7 \%$ at 4 months [27]. Another study suggests that the mRNA vaccine is $92 \%$ effective at keeping people from developing a high viral load 14 days after the second dose, but the effectiveness decreased to $90 \%, 85 \%$, and $78 \%$ after 30,60 , and 90 days, respectively [28]. However, reduced protection is not the only explanation for these observations. Individuals who were vaccinated early tended to be the healthcare workers in many countries, who were at a higher risk of infection than others vaccinated later; this could lead to data bias.

It is uncertain whether these drops in immunity reflect a decline in protection against the virus. Vaccines stimulate complex immune responses, including $\mathrm{B}$ and $\mathrm{T}$ cells, which may last longer than neutralizing antibodies. Vaccination initially produces a surge in the number of immune cells that generate antibodies and other molecules, which then slowly decline. This leaves a small pool of long-lasting "memory" B and T cells that patrol the body for future infections by that pathogen. A booster vaccine leads to the reproduction of $B$ cells, which elevates the levels of antibodies. A non-peer-reviewed study of healthcare workers in China found that $\mathrm{B}$ and $\mathrm{T}$ cells specific for SARS-CoV-2 could be detected five months after two doses of inactivated vaccine [29].

Early in the COVID-19 pandemic, there were a few "mutant" variant viruses detected with spike $(\mathrm{S})$ protein mutations in the receptor binding domain, which interacted with the angiotensin-converting enzyme 2 cell receptor [30]. Over time, a number of missense mutations in the $\mathrm{S}$ protein, especially in the receptor binding domain region, were observed in different variants of SARS-CoV-2. Some of them evolved to become more transmissible. The transmissibility of all five variants of concern (VOC) currently recognized by the WHO has increased to varying 
levels [31,32]. Notably, as the currently predominant SARS-CoV-2 strain, Delta (B.1.617.2) variant, is spreading globally, including in populations with high vaccination coverage, and it has the highest transmissibility compared to the original virus and Alpha, Beta and Gamma VOCs [31]. Studies showed that vaccination reduces the risk of Delta-variant infection and accelerates viral clearance. Nonetheless, the peak viral load of fully vaccinated individuals with breakthrough infections by Delta variant is similar to that in unvaccinated cases, which indicates that vaccination is not sufficient to prevent transmission of the Delta variant in household settings with prolonged exposure [33].

\section{The need for booster vaccines}

In the absence of reliable correlation for protection, researchers are looking for signs of vaccine efficacy in real-world data, from countries that have both high infection risk and advanced vaccination programs. The finding that early high vaccination coverage had not prevented infection rebound, due to antibody fading, in countries like Israel, which made the country employed one of the earliest and fastest booster vaccination programs in the world. On July 30, 2021, Israel began offering booster shots to anyone aged 60 years and older. According to recent studies, a third dose of PfizerBioNTech vaccine significantly lowers the risk of infection. A report from Israel's Ministry of Health evaluated 1.1 million Israelis over the age of 60 years who had received their first two doses at least five months earlier. It shows that a third dose reduces the rate of confirmed SARS-CoV-2 infection by more than 10-fold at least 12 days after administration [34]. In a preprint article, researchers found that the booster dose roughly halves a person's chances of testing positive for SARS-CoV-2 starting 7-13 days after the booster vaccination and further reduces it after 14-20 days [35]. The US and other countries have also started to give boosters to people at high professional risk of developing COVID-19 and to older adults or those with compromised immune systems. A trial tested various combinations of boosters, including using a different vaccine from the original inoculations [36]. Using a homologous booster dose increased neutralizing antibody titers $4.2-$ to 20 -fold, whereas heterologous boost increased titers 6.2- to 76-fold. However, these studies only cover a short period after the booster dose, and the duration of protection remains to be determined.

The Sinovac (CoronaVac) and Sinopharm vaccines from China have also been used in studies of booster vaccination to collect immunogenicity data. After 14 days from the third dose, the antibody levels rapidly increased to a higher level (geometric mean titer (GMT) of Group 2 up to 137.9 and GMT of Group 4 up to 143.1), approximately 3 to 5 times that after the second dose [37]. Another trial from China, not yet peer-reviewed, suggests that a third dose of CoronaVac increases neutralizing antibody levels, and a similar boost has been observed in studies of Sinopharm's vaccine [38]. Whether a booster vaccine offers benefits to people with weakened immune systems is debatable. A group from the University of Hong Kong recently reported the results of a randomized clinical trial of a third dose of CoronaVac or Pfizer-BioNTech (BNT162b2) vaccine in adults after an initial two doses of CoronaVac. At one month after the third vaccine, BNT162b2 elicited significantly higher surrogate virus neutralizing test (sVNT), spike receptor binding, spike N-terminal domain binding, and spike S2 subunit domain binding levels than CoronaVac; however, more participants from the BNT162b2 group reported side effects such as injection site pain, swelling, fatigue, and muscle pain than those who received CoronaVac. The mean suppression of the sVNT levels against the Wild-type, Beta, Gamma, and Delta variants in the BNT162b2 boosted group were $96.83 \%$, $92.29 \%, 92.51 \%$, and $95.33 \%$, respectively, which were significantly higher than those in the CoronaVac group (Wild-type, 57.75\%; Beta, 38.79\%; Gamma, 32.22\%; Delta, 48.87\%) [39]. Of note, a recent report showed that a third booster using a heterologous protein vaccine compared to the homologous inactivated vaccine, after previous administration of two-dose inactivated vaccines, could significantly increase the neutralizing antibody responses by 1.6, 2.4, 2.4 and 2.3 fold against the original viral strain, Beta, Gamma, and Delta variants, respectively [40]. The result indicated that the heterologous vaccine booster is superior to the homologous booster. These interesting data provide important evidence for establishing future global heterologous boosting strategies against COVID-19; although, homologous boosting can still be used in view of the easy access to vaccines already approved by the WHO and national regulatory agencies [41]. In addition to the potential advantage of heterologous over homologous boosting, the use of non-injection formulations for the booster has been proposed, such as the aerosolized adenoviral 5 vector-based formulation, with the potential advantage of inducing membrane immunity in the respiratory system [42]. On the other hand, a large proportion of organ transplant recipients on immunosuppressive drugs do not generate high levels of antibodies after two doses of vaccine. One study found that only half of transplant recipients produced detectable antibody levels [43]. Certainly, there is evidence that a booster dose can improve these titers, but for many individuals, the levels remain lower than those seen in other vaccination groups [44].

How soon the booster is needed may depend in part on the rate at which antibody levels decline. One modeling study estimated that low levels of antibodies are sufficient 
to offer significant protection against severe disease [45]. However, the current accumulated data suggested that a booster is necessary in approximately 6-12 months after the second dose. Multiple trials are currently underway to explore the effects of boosters and we will likely not have their results for several months.

\section{The world's first booster vaccination campaign}

As the first country with the highest COVID-19 vaccination rates in the world, Israel's primary vaccination campaign with two doses of mRNA vaccine (mostly Pfizer BNT162b2) covered more than half the population by the end of March 2021 [23]. The incidence of COVID-19/ million population/day dropped from 900 cases in midJanuary 2021 to fewer than two cases $[23,46]$ by June 2021 , together with a sharp drop in both severe illness and disease mortality (Fig. 3B) [47]. Nevertheless, with the emergence of the Delta variant of SARS-CoV-2 and in conjunction with the waning of vaccine-induced immunity, a rapid rebound occurred in the number of confirmed infections, severe illness, and disease mortality (Fig. 3B)
[23]. By the end of August 2021, more than 10000 nucleic acid confirmed cases were detected daily, and more than 600 cases were hospitalized with severe clinical symptoms [34].

To address the challenge of nationwide epidemic resurgence, the booster dose vaccine administration was approved by the Israeli authorities. The third dose BNT162b2 booster vaccination was first inoculated into high-risk populations on July 12, 2021, and then to persons aged 60 years or older starting on July 30, 2021 [34]. This mass booster-dose vaccination has greatly improved the overall booster vaccination level in Israel, reaching $70 \%$ of those primarily vaccinated, which is the highest in the world (Table 1 [23]). The results show that after 12 days of the booster dose, the neutralizing antibody levels increased approximately 10 times when compared to the levels after the second dose $[45,48]$. The rates of confirmed infection and severe illness were significantly lower in the booster group than in the non-booster group (by a factor of 11.3 and 19.5, respectively) in persons aged 60 years or older [34]. A related study showed that booster vaccination greatly elevated vaccine efficacy in preventing infection, hospitalization, intensive care unit admission, and death to $88 \%, 93 \%, 92 \%$, and $81 \%$, respectively (Table 2)

Table 1 The COVID-19 vaccine boosters administered throughout the world

\begin{tabular}{|c|c|c|c|c|}
\hline Time initiated & Country & Vaccine booster doses, million (\%) & $\%$ of total vaccine & $\%$ of total population \\
\hline $2021 / 7 / 5$ & France & $4.24(2.66)$ & 9.14 & 6.28 \\
\hline $2021 / 7 / 15$ & United Arab Emirates & $2.88(1.81)$ & 32.69 & 28.86 \\
\hline $2021 / 7 / 30$ & Israel & $4.04(2.54)$ & 70.14 & 43.47 \\
\hline $2021 / 7 / 30$ & Turkey & $12.87(8.08)$ & 25.97 & 15.14 \\
\hline $2021 / 8 / 5$ & Thailand & $2.71(1.70)$ & 7.57 & 3.87 \\
\hline $2021 / 8 / 8$ & Cambodia & $2.02(1.27)$ & 15.30 & 11.91 \\
\hline $2021 / 8 / 10$ & Chile & $7.24(4.55)$ & 46.03 & 37.7 \\
\hline $2021 / 8 / 15$ & Uruguay & $1.29(0.81)$ & 49.05 & 36.97 \\
\hline $2021 / 8 / 17$ & United States & $30.33(19.05)$ & 15.65 & 9.02 \\
\hline $2021 / 8 / 30$ & Canada & $0.82(0.52)$ & 2.86 & 2.13 \\
\hline $2021 / 8 / 31$ & Hungary & $1.76(1.11)$ & 30.4 & 18.32 \\
\hline $2021 / 9 / 1$ & Italy & 2.85 (1.79) & 6.52 & 4.73 \\
\hline $2021 / 9 / 5$ & Germany & $3.83(2.41)$ & 6.82 & 4.56 \\
\hline 2021/9/11 & South Korea & $1.35(0.85)$ & 3.37 & 1.93 \\
\hline $2021 / 9 / 24$ & Russia & $2.34(1.47)$ & 4.63 & 1.60 \\
\hline $2021 / 9 / 28$ & Singapore & $0.74(0.46)$ & 14.77 & 13.29 \\
\hline $2021 / 9 / 30$ & UK & $12.18(7.65)$ & 26.48 & 17.86 \\
\hline $2021 / 10 / 5$ & Spain & $2.65(1.66)$ & 7.07 & 5.19 \\
\hline $2021 / 10 / 15$ & China & $49.44(31.05)$ & 4.62 & 3.42 \\
\hline $2021 / 10 / 23$ & Iran & $0.42(0.26)$ & 1.05 & 0.50 \\
\hline $2021 / 10 / 23$ & Bulgaria & $0.013(0.01)$ & 0.78 & 0.19 \\
\hline $2021 / 10 / 25$ & Poland & $1.96(1.23)$ & 9.69 & 5.19 \\
\hline $2021 / 10 / 27$ & Brazil & $11.23(7.05)$ & 8.90 & 5.25 \\
\hline Total & & $159.203(100.00)$ & & \\
\hline
\end{tabular}

Reused from https://ourworldindata.org/covid-vaccinations [23] with permission. 
Table 2 The effect of booster vaccination doses of COVID-19 vaccines

\begin{tabular}{|c|c|c|c|c|c|c|}
\hline Study site & Treatment & $\begin{array}{l}\text { Interval between } \\
\text { 2nd and 3rd dose }\end{array}$ & $\begin{array}{l}\text { Preventing } \\
\text { infection }\end{array}$ & $\begin{array}{l}\text { Preventing } \\
\text { hospitalization }\end{array}$ & $\begin{array}{l}\text { Preventing ICU } \\
\text { admission }\end{array}$ & $\begin{array}{l}\text { Preventing } \\
\text { death }\end{array}$ \\
\hline Isreal [34] & $\begin{array}{l}\text { Pfrizer } 2 \text { doses }+ \text { Pfrizer } 3 \text { rd dose } \\
(7 \text { days after third dose })\end{array}$ & At least 5 months & $88 \%$ & $93 \%$ & $92 \%$ & $81 \%$ \\
\hline USA [49] & $\begin{array}{l}\mathrm{J} \& \mathrm{~J} 1 \text { dose }+\mathrm{J} \& \mathrm{~J} \text { 2nd dose } \\
(14 \text { days after third dose })\end{array}$ & 56 days & $94 \%$ & - & $100 \%$ & - \\
\hline \multirow[t]{3}{*}{ Chile [50] } & $\begin{array}{l}\text { Sinovac } 2 \text { doses }+ \text { AstraZeneca } \\
\text { 3rd dose (14 days after third } \\
\text { dose) }\end{array}$ & 5 months & $93 \%$ & $96.30 \%$ & $98.65 \%$ & - \\
\hline & $\begin{array}{l}\text { Sinovac } 2 \text { doses }+ \text { Pfrizer } 3 \text { rd dose } \\
(14 \text { days after third dose })\end{array}$ & & $90 \%$ & $87 \%$ & $92.68 \%$ & - \\
\hline & $\begin{array}{l}\text { Sinovac } 2 \text { doses }+ \text { Sinovac } 3 \text { rd dose } \\
\text { (14 days after third dose })\end{array}$ & & $80.20 \%$ & $88 \%$ & $85.10 \%$ & - \\
\hline
\end{tabular}

[34,49,50]. In recent weeks, newly confirmed COVID-19 cases and deaths in Israel have fallen to low levels due to the rapid scale up booster vaccination (Fig. 3B).

\section{Improving the overall vaccination strategy for better control of the COVID-19 pandemic}

Due to the combined challenges of SARS-CoV-2 variants, including the merging Omicron variant, as well as the waning vaccine immunity, booster vaccine doses will be needed more frequently and for more people. Many countries started booster jabs in high-risk professionals, older adults, and those with compromised immune systems. The decision to administer booster vaccines to the general population needs to be justified by a comprehensive risk/benefit analysis for that country, while simultaneously considering the issue of vaccine inequity, as raised by the $\mathrm{WHO}$.
The mRNA and viral vector vaccines have both higher efficacy and higher adverse effects, but with side effects that cannot be ignored, especially to certain age groups and patients with certain underlying conditions. A detailed risk/ benefit analysis of these vaccines is needed to address these group-specific issues, since there is a higher safety burden when a booster vaccine is used in the general population. Inactivated vaccines have lower efficacy in the prevention of mild cases but have lower side effects. There is a lower safety burden for inactivated vaccines when applied to the general population as a booster vaccine.

There is an urgent need to increase vaccination coverage in low-income countries, especially Africa (Fig. 5 [23]), and to address the inequity in SARS-CoV-2 vaccine distribution. Thus there is a heavy responsibility on higherincome countries in deciding whether mRNA vaccines should be used as a booster for the general population who have received two doses of vaccines. Since inactivated vaccines have lower neutralizing antibody titers compared
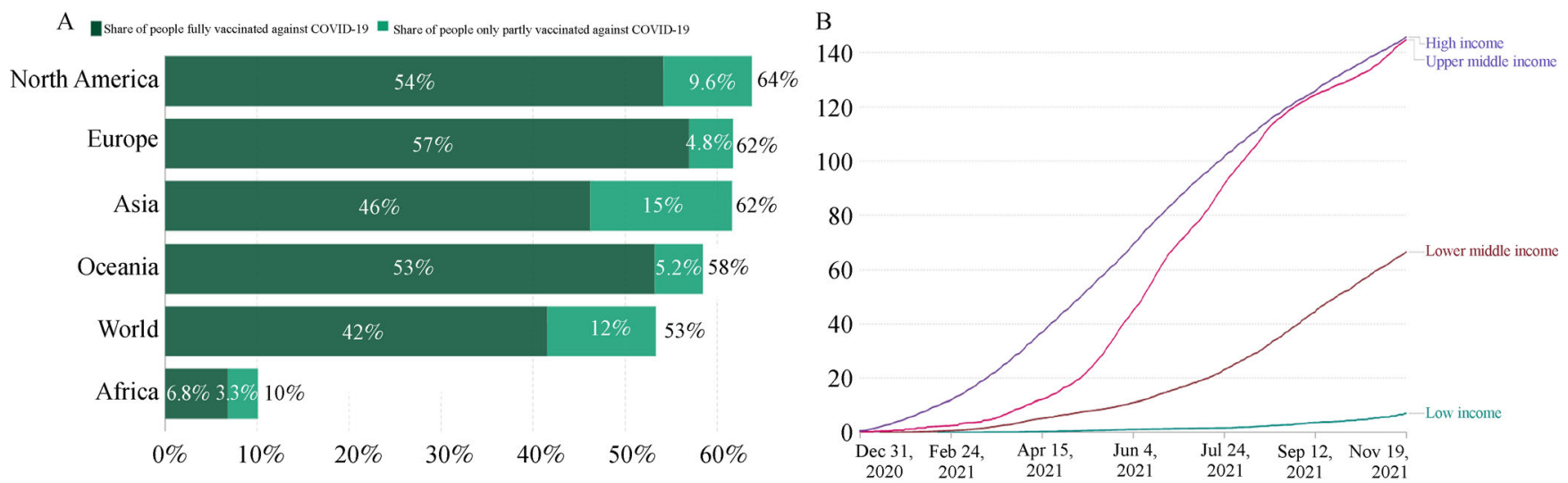

Fig. 5 Worldwide inequity in COVID-19 vaccine distribution. (A) COVID-19 vaccine administered in the world (November 19, 2021). (B) COVID-19 vaccine doses administered per 100 people. (Reused from https://ourworldindata.org/covid-vaccinations [23] with permission.) 
with mRNA vaccines, WHO's Strategic Advisory Group of Experts on Immunization has recommended providing a third dose of inactivated vaccine as a primary vaccination regimen for the older population [51]. There is less burden for countries to use a third dose of inactivated vaccines to increase vaccine efficacy. It may also be justified for China to administer booster vaccines to her population, who received mainly the inactivated vaccines $(>90 \%)$, since China has provided most of the vaccines, about half of the total SARS-CoV-2 vaccines used worldwide. Even though the SARS-CoV-2 incidence is low in China, it is challenging to determine the most appropriate vaccine combination, timing, and immunization strategy for the booster vaccination, considering the constant emergence of variants including Omicron and the high standards of the current dynamic zero-case COVID-19 control policy. Currently, the Chinese government is organizing comprehensive pilot research projects to collect data to support nationwide booster vaccination campaigns, while equally recognizing the importance of promoting high vaccination coverage in both older adults and children aged 3 to 11 years.

\section{Conclusions}

In the history of infectious disease control, one disease is usually controlled by one or two types of vaccines. Thanks to advances in science and technology, we have at least four kinds of vaccines to fight the COVID-19 pandemic, caused by a novel virus. Each vaccine has its own advantages and disadvantages. mRNA vaccines have higher efficacy, more side effects, and reduced accessibility due to the extremely low temperatures required for storage and transport compared with inactivated vaccines. Inactivated vaccines have reduced efficacy preventing mild cases, less side effects, and better accessibility due to the easier temperature requirements compared with mRNA vaccines. Viral vectors and protein vaccines have more balanced efficacy, safety and accessibility and can serve as both primary and booster jabs. Decisions should be based not on geopolitics and ideology, but on the needs and requirements of the people, young and old, with and without underlying disease. Singapore served as a good example for providing her people with the freedom to choose vaccine type (from mRNA, inactivated, or viral vector-based vaccines) according to their health conditions and requirements.

SARS-CoV-2 recognizes no borders, and no one is truly safe until everyone is protected. Vaccine inequity has become the biggest barrier for the COVID-19 pandemic control due to the huge disparity in vaccine accessibility; over $60 \%$ of the US and EU populations and around 50\% Asian population have been vaccinated, but only less than $7 \%$ of the African population have received vaccines.
China has already provided over 1.8 billion SARS-CoV-2 vaccines to over 100 countries and will provide an additional 200 million doses by the end of 2021 .

At the opening of the Forum on China-Africa Cooperation on November 29, 2021, Chinese President Xi Jinping announced that China will deliver another 1 billion doses of COVID-19 vaccines to Africa, with 600 million doses donations and 400 million doses through joint production between Chinese and African companies. President Xi also said that China will build 10 health projects in Africa and send 1500 doctors and public health experts to African to support local health work [52].

Collaboration, not competition or even confrontation, is the key to ensuring that sufficient vaccines are delivered to all people in both developed and developing countries. Only by sharing the SARS-CoV-2 vaccine, mankind can end the devastating COVID-19 pandemic in both the northern and southern hemispheres.

\section{Acknowledgements}

This work was supported by the National Natural Science Foundation of China (No. U20A20362).

\section{Compliance with ethics guidelines}

Yiming Shao, Yingqi Wu, Yi Feng, Wenxin Xu, Feng Xiong, and Xinxin Zhang declare that they have no conflict of interest. This manuscript is a review article and does not involve a research protocol requiring approval by the relevant institutional review board or ethics committee.

\section{References}

1. WHO. WHO Coronavirus (COVID-19) Dashboard. 2021. https:// covid19.who.int/ (accessed November 22, 2021)

2. Zhu N, Zhang D, Wang W, Li X, Yang B, Song J, Zhao X, Huang B, Shi W, Lu R, Niu P, Zhan F, Ma X, Wang D, Xu W, Wu G, Gao GF, Tan W; China Novel Coronavirus Investigating and Research Team. A novel coronavirus from patients with pneumonia in China, 2019. N Engl J Med 2020; 382(8): 727-733

3. Li Q, Guan X, Wu P, Wang X, Zhou L, Tong Y, Ren R, Leung KSM, Lau EHY, Wong JY, Xing X, Xiang N, Wu Y, Li C, Chen Q, Li D, Liu T, Zhao J, Liu M, Tu W, Chen C, Jin L, Yang R, Wang Q, Zhou S, Wang R, Liu H, Luo Y, Liu Y, Shao G, Li H, Tao Z, Yang Y, Deng Z, Liu B, Ma Z, Zhang Y, Shi G, Lam TTY, Wu JT, Gao GF, Cowling BJ, Yang B, Leung GM, Feng Z. Early transmission dynamics in Wuhan, China, of novel coronavirus-infected pneumonia. N Engl J Med 2020; 382(13): 1199-1207

4. Tan W, Zhao X, Ma X, Wang W, Niu P, Xu W, Gao GF, Wu G. A novel coronavirus genome identified in a cluster of pneumonia cases - Wuhan, China 2019-2020. China CDC Wkly 2020; 2(4): $61-62$

5. Wu F, Zhao S, Yu B, Chen YM, Wang W, Song ZG, Hu Y, Tao ZW, Tian JH, Pei YY, Yuan ML, Zhang YL, Dai FH, Liu Y, Wang QM, 
Zheng JJ, Xu L, Holmes EC, Zhang YZ. A new coronavirus associated with human respiratory disease in China. Nature 2020; 579(7798): 265-269

6. Zhang YZ, Holmes EC. A genomic perspective on the origin and emergence of SARS-CoV-2. Cell 2020; 181(2): 223-227

7. Harries D. CGTN Europe. Sinovac is biggest vaccine supplier, Pfizer trials pill in Russia: COVID-19 Daily Bulletin. 2021. https:// newseu.cgtn.com/news/2021-11-16/Sinovac-is-biggest-vaccinesupplier-Pfizer-pill-trial-COVID-Bulletin-15eXPcfZtBe/index.html (accessed November 19, 2021)

8. Tanriover MD, Doğanay HL, Akova M, Güner HR, Azap A, Akhan S, Köse Ş, Erdinç FŞ, Akalın EH, Tabak ÖF, Pullukçu H, Batum Ö, Şimşek Yavuz S, Turhan Ö, Yıldırmak MT, Köksal İ, Taşova Y, Korten V, Yılmaz G, Çelen MK, Altın S, Çelik I, Bayındır Y, Karaoğlan İ, Yılmaz A, Özkul A, Gür H, Unal S; CoronaVac Study Group. Efficacy and safety of an inactivated whole-virion SARSCoV-2 vaccine (CoronaVac): interim results of a double-blind, randomised, placebo-controlled, phase 3 trial in Turkey. Lancet 2021; 398(10296): 213-222

9. Jara A, Undurraga EA, González C, Paredes F, Fontecilla T, Jara G, Pizarro A, Acevedo J, Leo K, Leon F, Sans C, Leighton P, Suárez P, García-Escorza H, Araos R. Effectiveness of an inactivated SARSCoV-2 vaccine in Chile. N Engl J Med 2021; 385(10): 875-884

10. Palacios R, Patiño EG, de Oliveira Piorelli R, Conde MTRP, Batista AP, Zeng G, Xin Q, Kallas EG, Flores J, Ockenhouse CF, Gast C. Double-blind, randomized, placebo-controlled phase III clinical trial to evaluate the efficacy and safety of treating healthcare professionals with the adsorbed COVID-19 (inactivated) vaccine manufactured by Sinovac-PROFISCOV: a structured summary of a study protocol for a randomised controlled trial. Trials 2020; 21 (1): 853

11. Falsey AR, Sobieszczyk ME, Hirsch I, Sproule S, Robb ML, Corey L, Neuzil KM, Hahn W, Hunt J, Mulligan MJ, McEvoy C, DeJesus E, Hassman M, Little SJ, Pahud BA, Durbin A, Pickrell P, Daar ES, Bush L, Solis J, Carr QO, Oyedele T, Buchbinder S, Cowden J, Vargas SL, Benavides AG, Call R, Keefer MC, Kirkpatrick BD, Pullman J, Tong T, Isaacs MB, Benkeser D, Janes HE, Nason MC, Green JA, Kelly EJ, Maaske J, Mueller N, Shoemaker K, Takas T, Marshall RP, Pangalos MN, Villafana T, Gonzalez-Lopez A; AstraZeneca AZD1222 Clinical Study Group. Phase 3 safety and efficacy of AZD1222 (ChAdOx1 nCoV-19) Covid-19 vaccine. N Engl J Med 2021; [Epub ahead of print] doi: 10.1056/ NEJMoa2105290

12. Polack FP, Thomas SJ, Kitchin N, Absalon J, Gurtman A, Lockhart S, Perez JL, Pérez Marc G, Moreira ED, Zerbini C, Bailey R, Swanson KA, Roychoudhury S, Koury K, Li P, Kalina WV, Cooper D, Frenck RW Jr, Hammitt LL, Türeci Ö, Nell H, Schaefer A, Ünal S, Tresnan DB, Mather S, Dormitzer PR, Şahin U, Jansen KU, Gruber WC; C4591001 Clinical Trial Group. Safety and efficacy of the BNT162b2 mRNA Covid-19 vaccine. N Engl J Med 2020; 383 (27): 2603-2615

13. Al Kaabi N, Zhang Y, Xia S, Yang Y, Al Qahtani MM, Abdulrazzaq N, Al Nusair M, Hassany M, Jawad JS, Abdalla J, Hussein SE, Al Mazrouei SK, Al Karam M, Li X, Yang X, Wang W, Lai B, Chen W, Huang S, Wang Q, Yang T, Liu Y, Ma R, Hussain ZM, Khan T, Saifuddin Fasihuddin M, You W, Xie Z, Zhao Y, Jiang Z, Zhao G, Zhang Y, Mahmoud S, ElTantawy I, Xiao P, Koshy A, Zaher WA, Wang H, Duan K, Pan A, Yang X. Effect of 2 inactivated SARS-
CoV-2 vaccines on symptomatic COVID-19 infection in adults: a randomized clinical trial. JAMA 2021; 326(1): 35-45

14. Baden LR, El Sahly HM, Essink B, Kotloff K, Frey S, Novak R, Diemert D, Spector SA, Rouphael N, Creech CB, McGettigan J, Khetan S, Segall N, Solis J, Brosz A, Fierro C, Schwartz H, Neuzil K, Corey L, Gilbert P, Janes H, Follmann D, Marovich M, Mascola J, Polakowski L, Ledgerwood J, Graham BS, Bennett H, Pajon R, Knightly C, Leav B, Deng W, Zhou H, Han S, Ivarsson M, Miller J, Zaks T; COVE Study Group. Efficacy and safety of the mRNA1273 SARS-CoV-2 vaccine. N Engl J Med 2021; 384(5): 403-416

15. Logunov DY, Dolzhikova IV, Shcheblyakov DV, Tukhvatulin AI, Zubkova OV, Dzharullaeva AS, Kovyrshina AV, Lubenets NL, Grousova DM, Erokhova AS, Botikov AG, Izhaeva FM, Popova O, Ozharovskaya TA, Esmagambetov IB, Favorskaya IA, Zrelkin DI, Voronina DV, Shcherbinin DN, Semikhin AS, Simakova YV, Tokarskaya EA, Egorova DA, Shmarov MM, Nikitenko NA, Gushchin VA, Smolyarchuk EA, Zyryanov SK, Borisevich SV, Naroditsky BS, Gintsburg AL; Gam-COVID-Vac Vaccine Trial Group. Safety and efficacy of an rAd26 and rAd5 vector-based heterologous prime-boost COVID-19 vaccine: an interim analysis of a randomised controlled phase 3 trial in Russia. Lancet 2021; 397 (10275): 671-681

16. Sadoff J, Gray G, Vandebosch A, Cárdenas V, Shukarev G, Grinsztejn B, Goepfert PA, Truyers C, Fennema H, Spiessens B, Offergeld K, Scheper G, Taylor KL, Robb ML, Treanor J, Barouch DH, Stoddard J, Ryser MF, Marovich MA, Neuzil KM, Corey L, Cauwenberghs N, Tanner T, Hardt K, Ruiz-Guiñazú J, Le Gars M, Schuitemaker H, Van Hoof J, Struyf F, Douoguih M; ENSEMBLE Study Group. Safety and efficacy of single-dose Ad26.COV2.S vaccine against Covid-19. N Engl J Med 2021; 384(23): 2187-2201

17. Self WH, Tenforde MW, Rhoads JP, Gaglani M, Ginde AA, Douin DJ, Olson SM, Talbot HK, Casey JD, Mohr NM, Zepeski A, McNeal T, Ghamande S, Gibbs KW, Files DC, Hager DN, Shehu A, Prekker ME, Erickson HL, Gong MN, Mohamed A, Henning DJ, Steingrub JS, Peltan ID, Brown SM, Martin ET, Monto AS, Khan A, Hough CL, Busse LW, Ten Lohuis CC, Duggal A, Wilson JG, Gordon AJ, Qadir N, Chang SY, Mallow C, Rivas C, Babcock HM, Kwon JH, Exline MC, Halasa N, Chappell JD, Lauring AS, Grijalva CG, Rice TW, Jones ID, Stubblefield WB, Baughman A, Womack KN, Lindsell CJ, Hart KW, Zhu Y, Mills L, Lester SN, Stumpf MM, Naioti EA, Kobayashi M, Verani JR, Thornburg NJ, Patel MM; IVY Network. Comparative effectiveness of Moderna, Pfizer-BioNTech, and Janssen (Johnson \& Johnson) vaccines in preventing COVID19 hospitalizations among adults without immunocompromising conditions-United States, March-August 2021. MMWR Morb Mortal Wkly Rep 2021; 70(38): 1337-1343

18. Ella R, Reddy S, Blackwelder W, Potdar V, Yadav P, Sarangi V, Aileni VK, Kanungo S, Rai S, Reddy P, Verma S, Singh C, Redkar S, Mohapatra S, Pandey A, Ranganadin P, Gumashta R, Multani M, Mohammad S, Bhatt P, Kumari L, Sapkal G, Gupta N, Abraham P, Panda S, Prasad S, Bhargava B, Ella K, Vadrevu KM; COVAXIN Study Group. Efficacy, safety, and lot-to-lot immunogenicity of an inactivated SARS-CoV-2 vaccine (BBV152): interim results of a randomised, double-blind, controlled, phase 3 trial. Lancet 2021; 398(10317): 2173-2184

19. Chongqing Zhifei Biological Products Co. Ltd. A reminder announcement on key data from the phase III clinical trial of recombinant new coronavirus vaccine (CHO cell). 2021. http:// 
www.zhifeishengwu.com/news/gsyw/qyyw/2021-08-30/563.html (in Chinese) (accessed November 22, 2021)

20. Yang S, Li Y, Dai L, Wang J, He P, Li C, Fang X, Wang C, Zhao X, Huang E, Wu C, Zhong Z, Wang F, Duan X, Tian S, Wu L, Liu Y, Luo Y, Chen Z, Li F, Li J, Yu X, Ren H, Liu L, Meng S, Yan J, Hu Z, Gao L, Gao GF. Safety and immunogenicity of a recombinant tandem-repeat dimeric RBD-based protein subunit vaccine (ZF2001) against COVID-19 in adults: two randomised, doubleblind, placebo-controlled, phase 1 and 2 trials. Lancet Infect Dis 2021; 21(8): 1107-1119

21. Zhu FC, Guan XH, Li YH, Huang JY, Jiang T, Hou LH, Li JX, Yang BF, Wang L, Wang WJ, Wu SP, Wang Z, Wu XH, Xu JJ, Zhang Z, Jia SY, Wang BS, Hu Y, Liu JJ, Zhang J, Qian XA, Li Q, Pan HX, Jiang HD, Deng P, Gou JB, Wang XW, Wang XH, Chen W. Immunogenicity and safety of a recombinant adenovirus type-5vectored COVID-19 vaccine in healthy adults aged 18 years or older: a randomised, double-blind, placebo-controlled, phase 2 trial. Lancet 2020; 396(10249): 479-488

22. CanSinoBIO. NMPA accepts the application for conditional marketing authorization of CanSinoBIO's COVID-19 vaccine Convidecia $^{\mathrm{TM}}$. 2021. http://www.cansinotech.com/html/1///179/ 180/651.html (accessed December 9, 2021)

23. Mathieu E, Ritchie H, Ortiz-Ospina E, Roser M, Hasell J, Appel C, Giattino C, Rodés-Guirao L. A global database of COVID-19 vaccinations. Nat Hum Behav 2021; 5(7): 947-953

24. Dong E, Du H, Gardner L. An interactive web-based dashboard to track COVID-19 in real time. Lancet Infect Dis 2020; 20(5): 533 534

25. ECDC. Overview of the implementation of COVID-19 vaccination strategies and deployment plans in the EU/EEA. 11 November 2021. Stockholm: ECDC. 2021. https://www.ecdc.europa.eu/en/ publications-data/overview-implementation-covid-19-vaccinationstrategies-and-deployment-plans (accessed November 20, 2021)

26. Tartof SY, Slezak JM, Fischer H, Hong V, Ackerson BK, Ranasinghe ON, Frankland TB, Ogun OA, Zamparo JM, Gray S, Valluri SR, Pan K, Angulo FJ, Jodar L, McLaughlin JM. Effectiveness of mRNA BNT162b2 COVID-19 vaccine up to 6 months in a large integrated health system in the USA: a retrospective cohort study. Lancet 2021; 398(10309): 1407-1416

27. Thomas SJ, Moreira ED Jr, Kitchin N, Absalon J, Gurtman A, Lockhart S, Perez JL, Pérez Marc G, Polack FP, Zerbini C, Bailey R, Swanson KA, Xu X, Roychoudhury S, Koury K, Bouguermouh S, Kalina WV, Cooper D, Frenck RW Jr, Hammitt LL, Türeci Ö, Nell H, Schaefer A, Ünal S, Yang Q, Liberator P, Tresnan DB, Mather S, Dormitzer PR, Şahin U, Gruber WC, Jansen KU; C4591001 Clinical Trial Group. Safety and efficacy of the BNT162b2 mRNA Covid-19 vaccine through 6 months. N Engl J Med 2021; 385(19): 1761-1773

28. Pouwels KB, Pritchard E, Matthews PC, Stoesser N, Eyre DW, Vihta KD, House T, Hay J, Bell JI, Newton JN, Farrar J, Crook D, Cook D, Rourke E, Studley R, Peto TEA, Diamond I, Walker AS. Effect of Delta variant on viral burden and vaccine effectiveness against new SARS-CoV-2 infections in the UK. Nat Med 2021; [Epub ahead of print] doi: 10.1038/s41591-021-01548-7

29. Liu Y, Zeng Q, Deng C, Li M, Li L, Liu D, Liu M, Ruan X, Mei J, Mo R, Zhou Q, Liu M, Peng S, Wang J, Zhang H, Xiao H. Robust induction of $\mathrm{B}$ cell and $\mathrm{T}$ cell responses by a third dose of inactivated
SARS-CoV-2 vaccine. medRxiv 2021; 2021.09.12.21263373

30. Piplani S, Singh PK, Winkler DA, Petrovsky N. In silico comparison of SARS-CoV-2 spike protein-ACE2 binding affinities across species and implications for virus origin. Sci Rep 2021; 11(1): 13063

31. Campbell F, Archer B, Laurenson-Schafer H, Jinnai Y, Konings F, Batra N, Pavlin B, Vandemaele K, Van Kerkhove MD, Jombart T, Morgan O, le Polain de Waroux O. Increased transmissibility and global spread of SARS-CoV-2 variants of concern as at June 2021. Euro Surveill 2021; 26(24): 2100509

32. WHO. Classification of Omicron (B.1.1.529): SARS-CoV-2 variant of concern. 2021. https://www.who.int/news/item/26-11-2021-classification-of-omicron-(b.1.1.529)-sars-cov-2-variant-of-concern (accessed December 9, 2021)

33. Singanayagam A, Hakki S, Dunning J, Madon KJ, Crone MA, Koycheva A, Derqui-Fernandez N, Barnett JL, Whitfield MG, Varro R, Charlett A, Kundu R, Fenn J, Cutajar J, Quinn V, Conibear E, Barclay W, Freemont PS, Taylor GP, Ahmad S, Zambon M, Ferguson NM, Lalvani A; ATACCC Study Investigators. Community transmission and viral load kinetics of the SARS-CoV-2 delta (B.1.617.2) variant in vaccinated and unvaccinated individuals in the UK: a prospective, longitudinal, cohort study. Lancet Infect Dis 2021; S1473-3099(21)00648-4

34. Bar-On YM, Goldberg Y, Mandel M, Bodenheimer O, Freedman L, Kalkstein N, Mizrahi B, Alroy-Preis S, Ash N, Milo R, Huppert A. Protection of BNT162b2 vaccine booster against Covid-19 in Israel. N Engl J Med 2021; 385(15): 1393-1400

35. Patalon T, Gazit S, Pitzer VE, Prunas O, Warren JL, Weinberger DM. Short term reduction in the odds of testing positive for sARSCoV-2; a comparison between two doses and three doses of the BNT162b2 vaccine. medRxiv 2021; 2021.08.29.21262792

36. Atmar RL, Lyke KE, Deming ME, Jackson LA, Branche AR, El Sahly HM, Rostad CA, Martin JM, Johnston C, Rupp RE, Mulligan MJ, Brady RC, Frenck RW, Bäcker M, Kottkamp AC, Babu TM, Rajakumar K, Edupuganti S, Dobryzynski D, Posavad CM, Archer JI, Crandon S, Nayak SU, Szydlo D, Zemanek J, Islas CPD, Brown ER, Suthar MS, McElrath MJ, McDermott AB, O'Connell SE, Montefiori DC, Eaton A, Neuzil KM, Stephens DS, Roberts PC, Beigel JH; DMID 21-0012 Study Group. Heterologous SARS-CoV2 booster vaccinations - preliminary report. medRxiv 2021; 2021.10.10.21264827

37. Pan H, Wu Q, Zeng G, Yang J, Jiang D, Deng X, Chu K, Zheng W, Zhu F, Yu H, Yin W. Immunogenicity and safety of a third dose, and immune persistence of CoronaVac vaccine in healthy adults aged 18-59 years: interim results from a double-blind, randomized, placebo-controlled phase 2 clinical trial. medRxiv 2021; 2021.07.23.21261026

38. Li M, Yang J, Wang L, Wu Q, Wu Z, Zheng W, Wang L, Lu W, Deng X, Peng C, Han B, Zhao Y, Yu H, Yin W. A booster dose is immunogenic and will be needed for older adults who have completed two doses vaccination with CoronaVac: a randomised, double-blind, placebo-controlled, phase $1 / 2$ clinical trial. medRxiv 2021; 2021.08.03.21261544

39. Mok CKP, Cheng SMS, Chen C, Yiu K, Chan TO, Lai KC, Ling KC, Sun YX, Ho LL, Peiris M, Hui DS. A RCT of a third dose CoronaVac or BNT162b2 vaccine in adults with two doses of CoronaVac. medRxiv 2021; 2021.11.02.21265843 
40. Cao Y, Hao X, Wang X, Wu Q, Song R, Zhao D, Song W, Wang Y, Yisimayi A, Wang W, Zhang W, Du J, Yu H, Xie XS, Jin R. Humoral immunogenicity and reactogenicity of CoronaVac or ZF2001 booster after two doses of inactivated vaccine. Cell Res 2021; [Epub ahead of print] doi: 10.1038/s41422-021-00596-5

41. Ai J, Zhang H, Zhang Q, Zhang Y, Lin K, Fu Z, Song J, Zhao Y, Fan M, Wang H, Qiu C, Zhou Y, Zhang W. Recombinant protein subunit vaccine booster following two-dose inactivated vaccines dramatically enhanced anti-RBD responses and neutralizing titers against SARS-CoV-2 and variants of concern. Cell Res 2021; [Epub ahead of print] doi: 10.1038/s41422-021-00590-x

42. Wu S, Huang J, Zhang Z, Wu J, Zhang J, Hu H, Zhu T, Zhang J, Luo L, Fan P, Wang B, Chen C, Chen Y, Song X, Wang Y, Si W, Sun T, Wang X, Hou L, Chen W. Safety, tolerability, and immunogenicity of an aerosolised adenovirus type-5 vector-based COVID-19 vaccine $(\mathrm{Ad} 5-\mathrm{nCoV})$ in adults: preliminary report of an open-label and randomised phase 1 clinical trial. Lancet Infect Dis 2021; 21 (12): 1654-1664

43. Kamar N, Abravanel F, Marion O, Couat C, Izopet J, Del Bello A. Three doses of an mRNA Covid-19 vaccine in solid-organ transplant recipients. N Engl J Med 2021; 385(7): 661-662

44. Hall VG, Ferreira VH, Ku T, Ierullo M, Majchrzak-Kita B, Chaparro C, Selzner N, Schiff J, McDonald M, Tomlinson G, Kulasingam V, Kumar D, Humar A. Randomized trial of a third dose of mRNA1273 vaccine in transplant recipients. N Engl J Med 2021; 385(13): 1244-1246

45. Khoury DS, Cromer D, Reynaldi A, Schlub TE, Wheatley AK, Juno JA, Subbarao K, Kent SJ, Triccas JA, Davenport MP. Neutralizing antibody levels are highly predictive of immune protection from symptomatic SARS-CoV-2 infection. Nat Med 2021; 27(7): 1205-
1211

46. Muhsen K, Na'aminh W, Lapidot Y, Goren S, Amir Y, Perlman S, Green MS, Chodick G, Cohen D. A nationwide analysis of population group differences in the COVID-19 epidemic in Israel, February 2020-February 2021. Lancet Reg Health Eur 2021; 7: 100130

47. Goldberg Y, Mandel M, Bar-On YM, Bodenheimer O, Freedman L, Haas EJ, Milo R, Alroy-Preis S, Ash N, Huppert A. Waning immunity of the BNT162b2 vaccine: a nationwide study from Israel. medrxiv 2021; 2021.08.24.21262423

48. Pfizer. Pfizer quarterly corporate performance - second quarter 2021. 2021. https://investors.pfizer.com/events-and-presentations/ event-details/2021/Pfizer-Quarterly-Corporate-Performance-Second-Quarter-2021/default.aspx (accessed November 19, 2021)

49. Fox M. Two dose version of Johnson \& Johnson shot $94 \%$ effective against Covid-19, study finds. 2021. https://www.cnn.com/2021/09/ 21/health/johnson-vaccine-two-doses-booster/index.html (accessed November 20, 2021)

50. Yin N, Zhang X. Chilean research says that strengthening the needle can greatly improve the efficiency of the new crown vaccine. 2021. https://baijiahao.baidu.com/s?id $=1713052269746447683 \& w f r=$ spider\&for $=$ pc (in Chinese) (accessed November 20, 2021)

51. WHO. Interim statement on booster doses for COVID-19 vaccination. 2021. https://wwwwhoint/news/item/04-10-2021-interimstatement-on-booster-doses-for-covid-19-vaccination (accessed December 9, 2021)

52. Xinhua. Xi announces supplying Africa with additional 1 bln COVID-19 vaccine doses, pledges to jointly implement nine programs. http://www.news.cn/english/2021-11/30/c_1310341310. htm (accessed December 9, 2021) 